\title{
MODERN DEVELOPMENTS OF THE LAW OF PRIZE
}

That maritime importance which caused Great Britain to play so prominent a role in the control of Allied shipping during the war, placed upon the shoulders of the British courts ${ }^{1}$ by far the greater part of all the prize cases that arose during the period of hostilities from August 4, I9I4, to November II, I918. Not until I926 was the last prize case finally decided; and now we stand in a position where we can look back, unhampered by the enthusiasm and prejudices of wartime fever, over the changes that the late war has wrought in the fabric of the Law of Prize. To fully treat so great a subject within the limitations of a short essay is manifestly impossible. Not a few books ${ }^{2}$ have been written during the last few years, many of them covering only a small part of the field: all that can be accomplished in this essay is a brief survey which is designed to throw into relief the most fundamental among the many changes that the war has brought about in this field of jurisprudence.

In every branch of international law the growth tends to be intermittent, but this is probably more true of the Law of Prize than of any other part of that vast juristic structure. In times long past there may have existed a condition of human affairs in which war was considered to be a normal part of the everyday life of nations-in savage communities such conditions may prevail even at the present time! Nevertheless, among the nations of the civilized world, war comes to be a more and more infrequent occurrence: some of the greatest thinkers of this and of past generations have devoted themselves to attempts to attain a world-peace which shall be stronger and more enduring than any we have yet experienced, and even by the rank and file of the population of all civilized countries a state of war has come to be regarded as a spasmodic pathological condition which

${ }^{1}$ The Prize Courts of the U. S. did not sit during the war.

${ }^{2} C f$. C. J. Cozombos, The Lai of Prize; J. H. W. Verzijl, Le Droit des Prises de la Grande Guerre. 
destroys so much of the delicate machinery of international economic life that it is neither welcomed nor enjoyed.

It is not strange therefore that in I9I4 the Law of Prize should have remained in very much the same form that it had been given by the master hand of Lord Stowell during the $\mathrm{Na}$ poleonic Wars. Out of what cannot be called other than legal chaos, that great jurist had evolved a co-ordinated and intelligible system of law, which had been extended somewhat by the American courts during the Civil War-and it was the task of the British and allied Prize Courts during the war of I9I4-I9r8 to adapt the principles upon which that body of law was founded to the changed economic and political conditions in which the world found itself when war broke out. As Lord Birkenhead has well remarked: ${ }^{3}$

"The whole field of international law had been transformed since the Napoleonic war, and in particular the development of steam, electricity, cables, and of the character of modern weapons had rendered obsolete much of the learning which illustrated Lord Stowell's principles; and in many cases made it necessary to pursue these principles to their first origin, and, when established, to restate and adapt them."

Fortunately in Sir Samuel Evans the Prize Court had a jurist worthy of the task. Looking back over events at the present time, an observer cannot but be amused at the suggestion authoritatively made in 1914 that the President of the Admiralty, Probate and Divorce Division should delegate the work of the Prize Court to some solid and learned judge who had a greater acquaintance with that field. Nor can the student fail to appreciate that stupendous energy with which the President threw himself into the task of acquainting himself with all that had been written or decided in international law, so that he might worthily receive the torch from the hands of his great predecessor. To this worthiness for that high office the excellence of his judgments bears testimony.

\footnotetext{
${ }^{3} 2$ PoInts of VIEW 90.
} 
In one of his earliest decisions, which incidentally demonstrates the great knowledge of international law he had already acquired, Sir Samuel Evans stated clearly his recognition of the changes which that century had brought about in the economic life of the world.

"The decisions of a Court of Law, he said, should proceed upon well-defined principles. These principles have to be applied to ever-varying sets of facts. But the Court has the function and the duty not merely of deciding individual cases, but of determining them upon principles which shall be a guide to others as to what their positions and rights are in the eye of the law. In the domain of international law in particular, there is room for the extension of old doctrines, or the development of new principles, where there is, or is even likely to be, a general acceptance of such by civilized nations. Precedents dozcm from earlier days should be treated as guides to lead, and not as shackles to bind. But the guides must not be lightly deserted or cast aside." 4

It was in the spirit of this dictum that the Prize Court approached its colossal task, and every development which has come can be traced back logically in this manner to the sources from which it has sprung. An analysis of all the Prize decisions of the late war would prove an interesting task to one with more time and space at his disposal, but in this present essay it will be possible to deal only with a few of the principal judgments rendered in such outstanding fields as contraband and blockade, together with a short examination of the changes which the war has caused in the procedure and in the status of the Prize Court itself.

The rights of visit and search ${ }^{\top}$ by a belligerent war vessel of all private vessels met at sea, and of capture where there are sufficient grounds for a reasonable suspicion ${ }^{6}$ that the vessel or its cargo are subject to condemnation, are among the oldest rights known to the Law of Prize. These rights may be exercised

'The Odessa, [1915] P. 52; I B. \& C. P. C. I63 (Igr4).

"The Maria, I C. Rob. 340 (1799); The Zamora, [19r6] 2 A. C. 77. (1813).

-The Baron Stjernblad, [1918] A. C. 173; Locke v. U. S., 7 Cranch. 339 
in the case of vessels under the flag either of a belligerent power or of a neutral state. If the vessel which is ordered by a belligerent war vessel to heave-to for the purpose of visit and search be an enemy merchantman, it should be noted that

"the enemy merchant vessel may disregard this summons and do her utmost to escape. If brought to a standstill, she may use all the resources at her command to resist visit and search or capture. If she does so, she will of course become liable to attack and to the consequences thereof, and her crew will be treated as combatants. . . . Moreover, an (enemy) merchant ship may deliberately introduce arms on board, with the avowed intention of protecting herself, her passengers and crew, and her cargo. The introduction of armament intended to be used exclusively for defensive purposes is not contrary to international law and practice, but is sanctioned by the long established custom of maritime nations." 7

A neutral merchant vessel, however, may not under any circumstances resist visit and search.

After a vessel has been captured, the captor's right is one of possession only: the true owners are not divested of their property unless and until a sentence of condemnation has been duly passed thereon by a properly constituted prize court. As a great jurist has ably said:

"In modern times an additional formality has been required, that of sentence of condemnation in a competent court, decreeing the capture to have been rightly made jure belli. . . . From the moment that a sentence of condemnation becomes necessary, it imposes an additional obligation for bringing the property on which it is to pass into the country of the captor; for a legal sentence must be the result of legal proceedings in a legitimate court, armed with competent authority upon the subject matter and upon the parties concerned-a court which has the means of pursuing the proper enquiry and enforcing its decisions. These are the principles of universal jurisprudence applicable to all courts." 8

${ }^{7}$ F. E. Smith (Lord Birkenhead), The Destruction of Merchant ShIPS I9, 20.

${ }^{8}$ Lord Stowell in The Hendrick and Maria, 4 C. Rob. 43 (1799). 
Destruction of enemy merchant vessels therefore can seldom be given legal sanction. ${ }^{3}$ Exceptions, however, are made to the general rule, and the Oxford Manual of the Institute of International Law, I9I $3{ }^{10}$ provides that belligerents are permitted to destroy seized enemy ships only in so far as they are subject to confiscation and because of exceptional necessity, viz.: when the safety of the capturing cruisers or the success of the war operations in which they are engaged at the time is seriously involved. Similarly the Amercan naval instructions ${ }^{11}$ provide that

"If there are controlling reasons why vessels may not be sent in for adjudication, as unseaworthiness, the existence of infectious disease, or the lack of a prize crew, they may be appraised and sold; if this cannot be done they may be destroyed."

The destruction of neutral merchant ships must, as a rule, be altogether prohibited. If the captor is unable to bring the vessel into port for adjudication, he must release her. ${ }^{12}$ As the American government so clearly stated in 1915 :

"The sole right of a belligerent in dealing with neutral vessels on the high seas is limited to visit and search, unless a blockade is proclaimed and effectively maintained. To declare or exercise a right to attack and destroy any vessel entering a prescribed area of the high seas without first determining its belligerent nationality and the contraband character of its cargo would be an act so unprecedented in naval warfare that this Government is reluctant to believe that the Imperial Government of Germany in this case contemplates it as possible."13

In all previous wars these principles had been generally observed, as is sufficiently proved by the emphatic protests called

'The Stoer, [19i6] 5 L. R. P. C. I8.

${ }^{30} 26$ Annuatre de L'Institut de Droit Internationale (Igi3) 641 .

"U. S. Diplomatic Correspondence ( 1898 ) 775.

${ }^{12}$ British Memorandum to the London Naval Conference, 1909, in Lond. Decl. Doc. 6; Holland, Prize Manual, Article 303; Maisonaire v. Keating, 2 Gall. 325 - (1818).

"American note to Germany, February Io, I9I5. 
forth in the very few cases where they were disregarded. But in the late war the question of the destruction of prizes became of particular importance owing to the use of the submarine. That submarines can legitimately exercise the right of visit and search over enemy and neutral merchantmen, and capture them, there is not the slightest doubt. But a submarine can never spare a prize crew to navigate a prize into any port of adjudication, nor is there space enough on board a submarine to carry the crew of a destroyed vessel. It would seem, therefore, that a submarine cannot lawfully destroy a prize. According to the contention of the British government:

"A submarine fulfils none of these obligations (of visit, verification of the status and character of the vessel and cargo, and arrangements for the security of crew and passengers); she enjoys no local command of the waters in which she operates; she does not take her captures within the jurisdiction of a Prize Court; she carries no prize crew which she can put on board a prize; she uses no effective means of discriminating between a neutral and an enemy vessel; she does not receive on board for safety the crew and passengers of the vessel she sinks; therefore her methods of warfare are entirely outside the scope of any of the international instruments regulating operations against commerce in war time." 14

Nevertheless, despite the certainty of international law on this point, and in the face of the German Prize Ordinance, ${ }^{51}$ which enacted that, before the destruction of a prize, "the safety of all persons on board, and so far as possible their effects and the ship's papers, should be provided for," the practice of the German naval forces was quite the contrary. Enemy submarines destroyed several prizes after giving the crew ten minutes' notice to take to the boats and leave the ship: after February, I9I5, both enemy and neutral merchantmen were frequently torpedoed at

"British note to the U. S., March I, I9r5.

${ }^{25}$ Article 116.

${ }^{10}$ The Glitra (1915); The Indrani (1916) ; P. Fauchille et Cir. DE VISSCher, Jurisprudence Aillemande en Matiére de Prises 25, 74. 
sight. A justification of this practice was attempted by the German Prize Courts, on the ground that it was impossible for the submarines to take their prizes into port, and that the destruction was necessary in order to avoid recapture by the enemy. ${ }^{16}$ Such an argument clearly amounted to a breach of the existing principles of international law, which allow the sinking of enemy vessels solely for reasons of urgent military necessity. Circumstances which can be foreseen and are within the power or control of the belligerents do not afford any justification. Germany was at all times aware of the inability of her submarines either to carry a prize crew, or else conduct the captured vessels in for adjudication, and therefore, the use of submarines was unlawful unless they were able to conform to the established rules of naval warfare. The sinking of neutral vessels was, if comparison in illegality be possible, even more unlawful; yet in The Maria ${ }^{17}$ and The Laila ${ }^{18}$ the Berlin Supreme Court, in affirming the judgments of the Hamburg Court, decreed that the sinking of the neutral vessel was lawful, because the proximity of enemy cruisers gave rise to fears that she would be recaptured, and because the German submarines could not take her in.

In view of the fact that the existing rule of international law on this subject was confirmed by the adoption of Article I, of the treaty ${ }^{19}$ signed at Washington on February 6, I922, between the British Empire, the United States of America, France, Italy and Japan, the war has not at all changed the rules of Prize Law on this subject, but in view of the development of submarines even by the countries signatory to the treaty, one is compelled to doubt whether under the pressure of belligerent necessity in some future time a naval power might not be led to hold the German practice during the late war as a precedent! It is to be hoped that this thought is unduly pessimistic, but it is hard to see how submarines can be effectively used against

${ }^{37}$ J. A. P. 34 (1915).

${ }^{28}$ J. A. P. 8I (1916); Cf. Hamburg Prize Court in The Ares (1918), Grotius, Annuaire Internationale (I925) 255.

${ }^{19}$ I6 AMERICAN JouRnal OF INTERNATIONAL LAw (1922) 57 (supplement). 
the commerce of an enemy belligerent unless some change is made in the existing rules of international law.

Contraband of war is the designation of such goods as by either belligerent are forbidden to be carried to the enemy on the ground that they enable him to carry on the war with greater vigour. ${ }^{20}$ Whether or not an article is contraband hinges on two distinct elements, (a) whether it is susceptible of a belligerent use, and (b) whether it is consigned to an hostile destination. That the list of articles susceptible of a belligerent use should have been greatly expanded is by no means strange when one considers the scope and intensity of modern methods of warfare, and on that subject little need be written. The gradual development of the idea of what constitutes an hostile destination has, however, a very considerable interest.

As a corollary of the right of a belligerent to prevent such articles from reaching the enemy as would enable him to prosecute the war with greater vigor, a neutral vessel will render itself liable to capture and condemnation if it carries to the enemy goods which have been declared to be contraband. But what is meant by "carrying to the enemy"? Originally this meant the actual transportation of the goods into any enemy port in the case of absolute contraband, and in the case of conditional contraband their transportation into such an enemy port as might reasonably lead to the assumption that the goods would be used for naval or military purposes. ${ }^{21}$ "The destination of the vessel is conclusive as to the destination of the goods on board." The theory was first extended by Lord Stowell during the Napoleonic War. Clearly, he held, it was inconsistent with neutrality for the subject of a neutral state to interpose in time of war in the trade of a belligerent state and its colonies, when the neutral was forbidden by the laws of the belligerent state to take any part in such trade in time of peace. ${ }^{22}$ Such trade was equally illegal if the goods visited a neutral port en route from the colony to the belligerent.

\footnotetext{
${ }^{20} 2$ Oppenheim, International Law (3d ed.) 546.

${ }^{21}$ The Jonge Margaretta, I C. Rob. 189 (1799).

${ }^{22}$ The Maria, 5 C. Rob. 365 ( 1805 ); The William, 5 C. Rob. 385 (1806).
} 
"It is an inherent principle . . . that the mere touching at any port without importing the cargo into the common stock of the country will not alter the nature of the voyage, which continues the same in all respects, and must be considered as a voyage to the country to which the vessel is actually going for the purpose of delivering the cargo at its ultimate port." 23

Despite this extension, however, the principle still held good that the destination of the vessel was conclusive as to the destination of the goods on board. If a neutral port was the bona fide destination of a neutral ship, and the intended termination of the voyage on which she was captured, neither the ship nor the cargo (if it also was neutral) could be rightly condemned as prize. During the Civil War, however, the American Prize Courts carried the doctrine further by condemning vessels carrying articles contraband of war, which the belligerent could prove to be destined for the enemies' use, although the ship on which the goods were found was destined to take them only to some neutral port, and was ignorant of the ultimate hostile destination to which they were to be forwarded. ${ }^{24}$

This extension of the doctrine of continuous voyage-or as it is sometimes known in its modern form, the doctrine of continuous transports-did not meet with universal approval. But the late war was destined to witness an extension in its application very much greater than had previously been conceived possible. At the very first the compromise offered by the Declaration of London was rejected by the Allies, and the doctrine of continuous voyage was applied to the circuitous, or indirect carriage of conditional as well as absolute contraband. ${ }^{25}$ Successive orders carried the doctrine still further. First it was applied to voyages terminating at ports from which the enemy was known to have drawn supplies during the course of the war ${ }^{26}$ later it

${ }^{23}$ The Maria, supra note 22.

"The Bermuda, 3 Wall. 5I4 (1865); The Springbok, 5 Wall. I (I866); The Peterhoff, 5 Wall. 28 (i866).

${ }^{25} \mathrm{O}$. in C. Aug. 20, 1914 and Aug. 29, 1914

${ }^{*} \mathrm{O}$. in C. Oct. 19,1914 
was provided that destination creating absolute and conditional contraband shall be presumed to exist if the goods are consigned to or for a person who, during the present hostilities, has forwarded imported contraband goods to the territory belonging to or occupied by the enemy; ${ }^{27}$ while finally by the Maritime Rights Order in Council ${ }^{2 s}$ The Declaration of London was entirely abandoned, and it was provided in the simplest terms that

"the principle of continuous voyage or ultimate destination shall be applicable both in cases of contraband and blockade."

As a further protection of their belligerent interests, captors have claimed the right to throw upon neutral owners the onus of proving that their goods were not destined to the enemy territory. The basis on which this right was made to rest is set out by the Court in The Louisiana. ${ }^{29}$ The neutral trader is not in the position of a person charged with a criminal offence and presumed to be innocent unless his guilt is established beyond a reasonable doubt. He comes before the Prize Court to show that there was no reasonable suspicion justifying the seizure, or to displace such reasonable suspicion as in fact exists. The State of the captors is necessarily unable to investigate the relations between the neutral trader and his correspondents in enemy or neutral countries, but the neutral trader is or ought to be in a position to explain doubtful points.

Moreover, to strengthen their position still further, British Prize Courts during the war built up a presumption of hostile destination in the following cases: shipments to order, to the consignee's order or to unreal consignees; ${ }^{30}$ shipments where there was an absence or an apparent suppression of documentary evidence $;^{31}$ the existence of false papers or other fraudulent

$\approx$ O. in C. March 30, I916.

${ }^{28} \mathrm{July} 7, \mathrm{r} 9 \mathrm{r6}$.

$\rightarrow$ [1918] A. C. 46I; see also The Kronprinsessan Margareta, [1921] I A. C. 486; The Falk, 6 Ll. L. R. 503 (I92I).

${ }^{30}$ The Louisiana, supra note 29; The Sydland, [I917] P. I6r n. P. C. 74 .

${ }^{31}$ La Prosperité, Hay \& Marriott 295 (1779); The Kanakee, [I9I8] 8 L. R. 
concealments; $;^{32}$ the hostile association of consignors or consignees; ${ }^{33}$ shipments to consignees whose names appear on the Black List ${ }^{34}$ and statistical cases in which the imports of goods into a neutral country greatly exceeded in amount the import of similar commodities before the war. ${ }^{35}$

A survey of the decisions delivered by the Prize Courts during the late war cannot but lead to the conclusion that the conception of contraband as it existed previously to that war was based on assumptions which did not fully take into consideration the military, economic or scientific developments of the times. When, as in modern warfare, nations are mobilized so that every citizen is playing, directly or indirectly, some active part in the prosecution of the war, it is clear that all ports of the enemy become naval or military bases of supply. And when we consider the enormous de relopments and the high state of efficiency of railroad and coastwise transportation between adjacent countries, it is impossible to demand from a belligerent that he should refrain from interfering with shipments simply because they are consigned to a neutral port. Further, in almost every belligerent country during the late war the Government took control of all important supplies, and rationed them out to soldiers and civilians alike, thus creating a state of affairs in which conditional contraband and absolute contraband cannot be differentiated.

"This advance is noticeable, for it brings belligerents much nearer to the position they have always desired to attain, but have never yet reached in law. They have always desired to establish the right to stop all commerce with the enemy. If the enlargement of the lists of contraband can be maintained and the special protection hitherto given to conditional contraband is at an end for all practical purposesand both these assumptions seem to be necessary consequences of modern warfare-then the trade of neutrals which

P. 234

${ }^{32}$ The Lyngenficrd, [I9I6] 6 L. R. P. C. II5; The Axel Johnson, [19I7]

${ }^{33}$ The Tylsa, [1916] 5 L. R. P. C. 433.

${ }^{34}$ The Stanton, June 23, 1917; The Hakan, [1918] A. C. I48.

${ }^{35}$ The Uma, April 14, I919; The Baron Stjernblad, supra note 6; The Kim, I B. \& C. P. C. 405 (I915). 
is exempt from seizure can be reduced to a negligible quantity." 36

Blockade, which, although sometimes confused with contraband, is of a different nature, is the interception by sea of the coasts or ports of an enemy for the purpose of cutting off all communication. Its object is not merely to interrupt the importation of supplies, but to prevent export as well as import. ${ }^{37}$ Although there are no conventional rules prescribing the form which a blockade shall take, it is universally agreed that to be binding on neutrals the blockade must be effective, that is it must be such a blockade as to render hazardous the going-in or coming-out of any vessel from the blockaded port. ${ }^{38}$ The blockade must also be universal: that is to say egress and ingress must be interdicted impartially to vessels of all nations. ${ }^{30}$ It is moreover essential that it be limited to the ports and coasts of the enemy. ${ }^{40}$

When such a blockade has been properly established by the government of the belligerent country, and notification of its existence has been given to all neutral states and to the local authorities of the blockaded ports or coasts, any breach of blockade, or even an attempted breach will be considered an unneutral act by the belligerent who has established the blockade and will render the neutral vessel and cargo liable to condemnation.

Knowledge is of the essence of the offence, however, and a vessel will not be liable to condemnation when those in control of her were in fact ignorant of the existence of the blockade. ${ }^{41}$ But any vessel which has committed or attempted to commit a breach of blockade will remain in delicto until she has completed the voyage, provided the blockade continues in existence until that time. ${ }^{42}$

${ }^{36}$ Sir ERLe Richards, British Year Book of INt. LAW (1920-2I) 20.

${ }^{37}$ The Frederick Molke, I C. Rob. 86 (1798); 2 OpPenheim, InternaTIONAL LAW (3d ed.) 5I2.

${ }^{38}$ The Betsey, I C. Rob. 93 (I798); The Nancy, I Acton 57 (I809) ; Art. 4, Dec. of Paris, 1850; Art. 2, Dec. of Lond. r909.

${ }^{30}$ The Rolla, 6 C. Rob. 364 (I809) ; The Success, I Dod. I3I (18I2).

${ }^{10}$ The Jonge Pieter, 4 C. Rob: 79 (I80r).

"The Vrow Judith, I C. Rob. I50 (I799).

'The Welvaart van Pielaw, 2 C. Rob. 128 (1799). 
No cases of blockade appeared in the British Prize Courts during the late war, but it will be of interest to discuss the socalled "Long Distance Blockade" which has caused so much controversy. The measures were initiated by the Order in Council of March II, I915. ${ }^{43}$ and by the French Decree of March 13, $1915^{44}$ ordering the seizure and detention of all goods of German origin, ownership or destination, and their sequestration for the period of the war. By the Order in Council of January IO, $1917,{ }^{45}$ the blockade enforced against Germany was extended to the other enemy countries. In answer to the German declaration of unrestricted submarine warfare on February I, I9I7, a supplemental Order in Council ${ }^{46}$ decreed the capture and condemnation of all vessels carrying goods of enemy origin or destination encountered at sea on their way to or from a port in any neutral country affording means of access to the enemy territory, unless such vessels had previously called at a British or Allied port.

This long-distance blockade was promptly challenged by the neutral powers, ${ }^{47}$ who alleged that the blockade was illegal because (a) the measures amounted to a blockade of neutral ports-"so great an area of the high seas is covered and the cordon of ships is so distant from the territory affected that neutral vessels must necessarily pass through the blockading force to reach important neutral ports which Great Britain, as a belligerent, has no legal right to blockade"; (b) the blockade did not bear with equal severity upon all neutrals, since Scandinavian trade was still possible across the Baltic; and (c) the blockade was not effective. In reply England maintained ${ }^{48}$ that the measures amounted to no more than an adaptation of the old principles of blockade to the peculiar circumstances of the World War, and that it was in harmony with the spirit of the old rules.

"Stat. Rules \& Orders, I9I5, iii, I05.

"Journal Officiel, March 16, 1915, 1388.

${ }^{45} \mathrm{~S}$. R. \& O. 19I7, $95 \mathrm{r}$.

"Ibid. 952.

"Particularly the U. S. in notes dated Apr. 2, 19r5 \& Nov. 5, 1915; Parl. Papers, Misc. No. I4 (1916), Cd. 8233 p. I, No. I5 (IgI6) Cd. 8234 p. 2.

"In notes dated July 23, 1915 and April 24, 1916, Parl. Papers, ibid. 
With regard to the first neutral contention, England maintained that she had a right to apply the blockade to goods reaching the enemy by way of neutral port, and that every effort was made not to interfere with bona fide neutral commerce. In reply to the contention that the blockade was not impartial, it was maintained that the passage of commerce to a blockaded area across a land frontier, or across an inland sea, has never been held to interfere with the effectiveness of the blockade. If the doctrine of continuous voyage may rightly be applied to goods going to Germany through Rotterdam, on what ground can it be contended that it is not equally applicable to goods with a similar destination passing through some Swedish port and across the Baltic, or even through neutral waters only? Moreover it was maintained that the blockade was as effective as any blockade had ever been in the past.

An examination of the writings on the subject ${ }^{40}$ and a study of the changes which the past century has witnessed both in the machinery of commerce and of naval weapons, leads to the conclusion that the long distance blockade, applied to enemy ports and coasts, is perfectly in accordance with the principles of international law. Not so, however, with the extension of the blockade to neutral ports and coasts, since such an extension violates the fundamental rule on which the whole conception of neutrality is based. Whatever the necessities of cutting off the maritime trade of their enemy may require of belligerents, neutrals are entitled to demand that the free admission to and exit from their ports of all lawful traffic be not interfered with by the blockading forces.

Thus the British naval operations were upheld by the Prize Courts not on the ground of blockade but on the principles of retaliation. ${ }^{\overline{0} 0}$ Resort to retaliatory measures is only possible when a belligerent can establish that such measures were taken under the pressure of absolute necessity, being the only mode of redress for a violated obligation of the enemy. They must

19 Among others Sir John Macbonell, Transactions of the Grotius Society (I9I6) 100 ; and H. H. L. BeLLOT, INTERnational LAW Notes (1918) 67.

${ }^{\circ}$ The Stigstad, [1919] A. C. 279; The Leonora, [1918] P. I82. 
further constitute the only means of deterring the enemy from a repetition of the same or similar breaches of the law. ${ }^{51}$ But when such conditions exist, it has been held that the right of retaliation enables a belligerent to cast aside for the time being all the accepted rules governing neutral trade. ${ }^{52}$ That this is unpalatable to a neutral cannot be denied, but retaliation is a right of the beliligerent, not a concession of the neutral-and the only limitation placed upon it is that the belligerent can only avail himself of it in time of absolute necessity.

Occupying à place of lesser importance, but of no less interest, th the structure of the Law of Prize is the right of angary, which Oppethiheitín sticcinctly defines as

"a right of belligerents to destroy or use in case of necessity, for the purpose of offense and defense, neutral property in their territory, or in enemy territory, or on the open sea." 53

Although such a right has frequently been claimed by belligerents, it must be admitted that there are considerable differences of opinion as to the precise conditions under which it can lawfully be exerted. Prior to the war only one British prize decision on this subject is to be found, ${ }^{54}$ in which it was decided that there may be circumstances of necessity in which the right of self-defense supersedes all inferior rights and dispenses with the usual modes of procedure.

At best, this decision is vague and of little value to the student who wishes to determine precisely the limits of the rights of a belligerent. But early in the late war the whole subject of angary came up for discussion in the British courts in the now famous case of The Zamora. ${ }^{55}$ Sir Samuel Evans' judgment was founded on the doctrine that it was within the power and prerogative of the Crown to make a general order for the requisition

\footnotetext{
${ }^{2}$ Hali, A Treatise on INt. Law (7th ed.) $497 ; 2$ Westlake, INt. Law (2d ed.) 126.

$: 2$ The Fox, Edw. 3II (1807); The Stigstad, sipra note 50.

${ }^{23}$ OPPen heIs, op cit. supra note 37,506 .

"The. Curlew, Stewart's Vice-Admiralty Cases (Nova Scotia) 312 (1812).

$\sim$ [1916] P. 27.
} 
of neutral property. This however, was reversed on appeal, ${ }^{\overline{0} 6}$ the Privy Council holding that there was no such general right known to the law of nations by which a belligerent could exercise compulsory purchase over goods belonging to neutrals, even in its own territory, while the suggestion of a power to requisition on the high seas, or on property brought into the belligerent's port for purpose of visit and search was entirely repudiated. The conclusion reached by their Lordships was that there undoubtedly existed special reasons which conferred upon a belligerent the power to requisition property in the custody of its Prize Court pending a decision as to condemnation or release of such property, but this power was strictly limited. It could only be exercised subject to compensation and where all of the following conditions occurred: (a) the neutral vessel or goods ought to be urgently required for use in connection with the defense of the realm, the prosecution of the war, or other matters involving national security; (b) there must be a real question to be tried, so that it would be improper to order an immediate release; and (c) the right should be enforced by application to the Prize Court, which must determine judicially whether under the peculiar circumstances of the case the right is exercisable. In every instance it was for the Court, and not the executive of the belligerent State, to decide whether the power to requisition neutral property could be lawfully asserted.

The right of angary was also resorted to in the late war by the French and German military authorities, which on several occasions requisitioned neutral property. The legality of the step was not questioned by their respective Prize Courts, and no special conditions were raised on its application, other than the payment of indemnity to the neutral owners. ${ }^{57}$ The continental decisions therefore make little or no change in international law on this point, but so far as the decisions in the British Prize Court become an international precedent, a valuable guarantee is provided to neutrals in that the legality of the exercise of the bel-

\footnotetext{
"[Igr6] 2 A. C. 77. Cf. The Canton, [1917] A. C. 102.

${ }^{s 7}$ French Prize Court in The Rioja (No. 2) and The Teresa Fabregas, J. O. December 2 and 22, I915, 8778, 9410 ; The German Supreme Court in The Pitea und Presto (Igr8), Grotius, ANNUAIRE InTERNATIONAIE (I924) 225.
} 
ligerent's right to requisition will be determined by a judicial tribunal and not merely by an order from the executive.

Amiong the greatest changes that the war has wrought, is that which has occurred in the procedure of the Prize Court itself. Admittedly the procedure of a court is not substantive law, but changes in the procedure of a court applying essentially the law of nations may go far to mould the development of those juristic principles which are the foundation of that legal system. The position of a claimant in a Prize Court is peculiar and exceptional: although it is the belligerent state which comes forward to ask for condemnation and so would under ordinary rules bear the hurden of proof, the onus is thrown on the claimant to satisfy the Court that the property captured is not subject to confiscation. ${ }^{58}$ As Sir Samuel Evans pointed out, ${ }^{59}$

"It is the theory of the old Prize Courts that the Crown themselves capture or seize a vessel, and the persons whose property is seized must come here in the course of the proceedings prepared to give grounds why their property is not confiscable. It is enough for the Crown to say, "we regard this vessel or this cargo as prize and we seize it as prize and we issue a writ against you in which we tell you that we are going to ask the Court for its condemnation.' Thereupon the parties must file their claim and it is for them to show that the seizure and capture by the Crown were not rightfully made."

This being so, upon what evidence is the Prize Court to base its judgment? According to the practice of the last century, captors were in no case allowed to give evidence: the Prize Court is a court of civil law and knows not the contest between two equally matched parties which occurs in a common law court. As an able jurist of the nineteenth century has written:

"The ship must be brought by her own shozving within certain plain rules, unless, as a matter of grace, further proof is allowed her to excuse herself."

* The Walsingham Packet, 2 C. Rob. 77 (1799); The Countess of Lauderdale, 4 C. Rob. 283 (I802).

"The Antares, I B. \& C. P. C. 26r (Igr5). Cf. The Sydland, supra note 30. 
The evidence to acquit or condemn the vessel, with or without costs, and damages, must in the first instance come merely from the ship taken, that is from the papers found on board and from the examination on oath of the master and the other principal officers and of the crew. ${ }^{60}$ If there does not appear from this evidence ground to condemn an enemy's property or contraband goods going to the enemy, there must be an acquittal unless from the aforesaid evidence the property shall appear so doubtful that it is reasonable to go into further proof thereof. ${ }^{61}$

Such a ruling would have rendered impossible the application of the doctrine of continuous voyage in the form in which it was applied during the war. In fact, by the first British Prize Court Rules ${ }^{62}$ this was changed and the evidence of captors was allowed in the first instance. This change is very radical: vessels or cargoes, apparently innocent, may now be seized on reasonable suspicion while efforts are being made to obtain evidence from extraneous sources which will justify the detention and permit the commencement of Prize proceedings. Moreover, the captors can now establish the ultimate destination of goods in cases in which it would have been hopeless to attempt to do so under the old practice. The great bulk of contraband going to Germany during the war was consigned in the first instance to neutral ports. The ship's papers naturally would in no such case reveal the ultimate destination of the goods, nor would the standing interrogatories administered to the master or the crew reveal any facts material to the issue, because in modern times the master and crew of a vessel no longer stand in that close personal relationship to the owners of the cargo which made their evidence so valuable to a Prize Court during the $\mathrm{Na}$ poleonic Wars. But captors with this new liberty of proof have been able to establish the enemy destination by other evidence, such as intercepted cablegrams or correspondence. Further, in cases where direct proof of enemy destination, even by these

"The Haabet, 6 C. Rob. 54 (I805); The Aline \& Fanny, ro Moore P. C. 491 ( 1856$)$.

${ }^{o 1}$ Letter addressed by Lord Stowell and Sir J. Nicholl to Mr. Jay, U. S. Ambassador in London, September 10, 1794, I AM. STAte PAPERS 494 .

$=0$. in C. August 5, I9I4. 
methods, could not be obtained, other evidence was admitted to shift the onus onto the claimants of showing that the ultimate destination of the goods was neutral, e. g., where it could be proved that the consignee was trading principally with the enemy or was a person not normally engaged in trade who had suddenly become involved in large transactions. Indeed, Sir Samuel Evans stated in The Maracaibo ${ }^{63}$ that experience had amply shown that often it was only by the interception of letters or cables or wireless messages that the ingenuity and multitudinous character of the devices and shams resorted to in carrying on contraband trading could be detected and disclosed.

The result is that any evidence either by witness, by ship's papers, by affidavit or by any other document which is material to the issue is admissible. The widest range of proof is consequently allowed to both parties. It was held by the Privy Council in The Consul Corfitzon ${ }^{64}$ that all documents which threw light on the course and nature of the claimant's business both before and after the outbreak of war was material; and by Sir Samuel Evans in The Bravo ${ }^{65}$ that the Court had the right to ask claimants to produce all their books and, in case of a persistent refusal to strike out their claim. In other words, the judge is entitled to demand "a full and complete discovery" of all matters involved in the issue in dispute: moreover, it is his duty to take into consideration all the facts, and he is not "to shut his eyes to what is generally passing in the world." 66

Although the change was not very warmly welcomed in some quarters, the new method is very much better in practice than the old one. Indeed it is the only method possible when we consider the developments that have occurred in transportation and communications during the past century. In the time of the Napoleonic Wars, as has already been pointed out, the master and crew of the vessel were usually well acquainted with the owners of the cargo and with the nature of the transaction

\footnotetext{
${ }^{63}$ [Igr6] P. 284.

[I917] A. C. 550. Cf. The Edna, [I92I] I A. C. 735.

es Judgment of October I7, I9I7.

"The.Kim, [19I5] P. 215.
} 
between consignor and consignee. At that time also there were no fast mail vessels or cables which might convey supplementary evidence. Moreover, the change is beneficial to the claimant as well as to the captor. Under the former procedure the presentation of a false or fraudulent claim was fatal to the claimant's cause, and he was never allowed to offer further proof: by the new practice an explanatory or exculpatory evidence is accepted, and the matter is decided by taking into consideration all the relevant facts. ${ }^{67}$ From all viewpoints, therefore, the change is desirable, and it is significant that it was also made in the Prize Courts of both France ${ }^{68}$ and Germany. ${ }^{69}$

In order to widen still further the scope of the Prize Court, and to render it even more impartial than heretofore, it was held that an alien enemy might enter an appearance in a British Prize Court on all matters affecting his rights which were governed by an international treaty. ${ }^{\mathbf{7 0}}$ Nor was England alone in making this change, for leave to enter an appearance in order to defend and uphold any rights to which he thought himself entitled was granted to an alien enemy by the French, ${ }^{71}$ Italian, ${ }^{72}$ Russian, ${ }^{73}$ German, ${ }^{74}$ and other Prize Courts. That this brings the Prize Courts of a belligerent one stage nearer to that impartial international tribunal which is universally desired needs little demonstration.

Although Prize Courts are set up by the several states, the inherent independence of these courts was well stated by Sir Samuel Evans and upheld by the Privy Council in the case of The Zamora, ${ }^{75}$ where it was held that, under the terms of the con-

of The Astyanax, 6 Ll. L. R. 386 (I92I); The Castor, ibid. I43 (I92I).

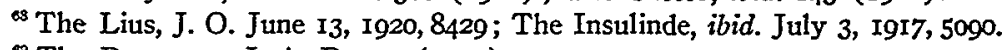

"The Davanger, J. A. P. I77 (I9I7).

${ }^{70}$ The Möwe, [19I5] P. I; The Vista, [192I] I A. C. 774.

71 The Czar Nicholai II, J. O. April I9, I915, 2369.

72 The Cervignano, Gazetta Officiale, April 23, 19I7, No. 93.

73 The Khaifa, judgment of February I0, I9I5.

7 The Fenix, J. A. P. 242 (1914).

${ }^{75}$ I B. \& C. P. C. 309 (1915) ; [1916] 2 A. C. 77. 
stitution of the Prize Court, the law it administered was international law and the King in Council had no power to prescribe or to alter the law to be administered, although the Court will give effect to those Orders in Counsel which amount to a mitigation of the Crown's rights in favor of an enemy or a neutral. The importance of this decision cannot be overestimated. As Prof. Pearce Higgins ${ }^{76}$ has pointed out, neutral states have complained of the Orders in Council, and in reply to the advice that their complaints should be taken to the Prize Court they said in effect: "What is the use of going to a Court which is under the control of the government?" The judgment in The Zamora recalled the famous dictum of Lord Stowell in The Maria ${ }^{77}$ that it is the duty of a judge of a British Court of Prize to consider himself as stationed there to administer with indifference that justice which the law of nations holds out without distinction to independent states, whether neutral or belligerent.

It must be confessed that a study of the decisions of the belligerent courts and of the Prize Regulations of the belligerent states shows that in the past Prize Courts are in the main partly administrative and partly judicial bodies, and that as to the law they administer they are under executive control. (This, however, does not apply to the Courts of the United States and of Great Britain-both of which have shown themselves to be purely judicial tribunals.) The Report of the Commission on the International Prize Court Convention at the Hague Conference in 1907, while stating that eminent magistrates had made declarations asserting the independence of Prize Courts of arbitrary orders of the Executive, added:

"As a matter of fact, the instructions and orders of a government are presumed by the Courts which it constitutes to conform to the law of nations, and we find no case where a Prize Court has refused to apply an order of its government on the ground that it is contrary to the law of nations." 78

\footnotetext{
${ }^{36}$ Colombos, Law of Prize (1926) vi.

"I C. Rob. 340 (1799).

${ }^{78}$ I ACtes et Documents 180.
} 
The Zamora, The Hakon ${ }^{79}$ and The Proton ${ }^{80}$ now provide examples; and in the two latter cases the Prize Court expressly declined to enforce provisions of the Declaration of London, which they held were not in conformity with international lawalthough the provisions were expressly prescribed by Orders in Council.

This recognition of the independence of a Prize Court from the executive orders of its government opens up a wide field of speculation. If a Prize Court is independent of the State, to what extent can it criticise the policy of its government? Further, if it is competent to make such criticism of national policy, ought it not to have before it all the material necessary to enable it to form a sound judgment? But, above all else, since a Prize Court is to be independent of a belligerent government, might not that essential independence be best ensured and maintained by the establishment of an International Prize Court, which would from its composition be free from that suspicion of national bias which may exist in the mind of a neutral claimant regarding even the most impartial of belligerent tribunals? After the fate of the Declaration of London and of that ideal of an International Prize Court which led to the London Naval Conference, there is a natural hesitancy in putting forward the proposal-yet there are evidences that the conceptions of Prize Law which govern the several national tribunals have fewer points of discord than were found to exist in I909. During the interval Prize Law has developed greatly: the underlying principles have been laid bare and adapted to modern conditions. Much that has been found to be obsolete has been discarded, and the traces of uniformity in the national application of the fundamental principles are sufficient to give rise to the thought that the ideal of an International Prize Court is less impracticable than it seemed twenty years ago.

University of Pennsylvania.

\section{F. Cyril James.}

\footnotetext{
${ }^{79}$ [I9r6] P. 266; [1918] A. C. I48.

${ }^{80} 2$ B. \& C. P. C. 107 (I915) ; [1918] A. C. 578 .
} 